spaces were as capable of rearticulation as those from the early modern period. This is a result, of course, of the format rather than the material, which is undeniably both rigorous and stimulating, and the editors are very clear in their introduction that the volume is 'a pilot study' (10). The inspiring scholarship it contains is of such a high calibre that it will doubtless fulfil the editors' aspiration to spur other scholars into more detailed and extensive investigations of their own.

\title{
Notes
}

1 The term 'taskscape' is appropriated from the work of Mike Pearson to articulate how a landscape is both changed by human actors in the present whilst remaining permanently inscribed by the past.

2 Julie Sanders and Jacqueline Jenkins have edited a partner volume to Performing Environments of similarly longue durée: Editing, Performance, Texts: New Practices in Medieval and Early Modern Drama (Basingstoke, 2014).

3 Josephine Machon, Immersive Theatres: Intimacy and Immediacy in Contemporary Performance (Basingstoke, 2013).

4 Josephine Machon, (Syn)Aesthetics: Redefining Visceral Performance (Basingstoke, 2009); Richard Schechner, Environmental Theatre (New York, 1994); Laura Cull, Theatres of Immanence: Deleuze and the Ethics of Performance (Basingstoke, 2012).

\section{Vernon Guy Dickson. Emulation on the Shakespearean Stage. Farnham: Ashgate, 2013. Pp 216.}

C.K. ASH

Early Theatre 18.1 (2015), 155-8

DOI: http://dx.doi.org/10.12745/et.18.1.2572

Vernon Guy Dickson's monograph is a densely packed guide to rhetorical emulation in Renaissance tragedies. His bardocentric title is not so much misleading as a disservice to his topic, which investigates emulative theory from ancient Roman rhetoricians through to drama written a decade after Shakespeare's death. This is such a massive undertaking that Dickson's extensive knowledge sometimes inhibits his ability to sustain in-depth analysis. At 
times, he gives the impression of an explorer so comfortable with his terrain that he has difficulty remembering to leave trail markers for the novices attempting to follow his path. Of all possible problems to have when treating intricate linguistic patterns spanning millennia, this scope is both understandable and forgivable.

The book breaks down into five chapters, with two further short chapters as preface and afterword. Following the opening survey, the four main chapters each address a single play: Titus Andronicus and Hamlet by William Shakespeare, Catiline his Conspiracy by Ben Jonson, and The Roman Actor by Philip Massinger. In the preface, Dickson lays out the book's structure, briefly introduces his broad definitions, and identifies his analytical strategy. Bolstered by early modern definitions of classical emulative theory, his arguments look at the application of rhetorical emulation on the stage. This approach has foundations in René Girard's work $A$ Theatre of Envy: William Shakespeare (xi) and widens the scope of new historicist studies to examine how rhetorical theory influenced the individual within larger cultural and social constructions of self (xvii). Chapter 1 continues this broad view to give a dizzying survey of classical rhetoricians and a working definition of emulative rhetoric in non-dramatic early modern writing. Emulation, unlike its negative counterpart, envy, is a form of learning that combines imitation and innovation. In the Renaissance, Dickson argues, emulation could teach virtuous action, but it could also suggest more radical changes (24-5). He sees non-dramatic writing using emulation to shape individual character and society, whereas dramatic writing shows the sustained embodiment of emulation - the enactment of ideas, a concept to which he returns frequently throughout the book.

Chapter 2 deals solely with Titus Andronicus, a play in which Dickson sees emulation authorizing Shakespeare's language (29). He focuses on linguistic and structural patterns in the play to discuss Shakespeare's command of ancient texts and familiarity with contemporary writers. Particularly interesting is the analysis of Lavinia's death for the differences between emulative theory and real application, differences showcased in Titus's set piece tutorial that ends in the near-parodic enactment of moralizing emulation. Chapter 3 explores Hamlet's ability to self-fashion within a play that presents him as a dramatic manifestation of emulative patterns. Dickson provides a list of Hamlet's emulative models that shines a new light on exactly why the prince has trouble deciding on a single course of action (67-8). The play's concern with decorum shows in Hamlet's advice to the players, which sets up 
appropriate action and embodiments that will feed into the emulative scene to follow (82-3). Perhaps a troubling dramatic side effect of this concentrated emulation, however, is the disconnect between Hamlet's fictionality and his functionality. Dickson presents linguistic patterns as accretive, but a performer reading this might be left wondering how to use rhetoric more actively to help the audience experience those patterns.

Chapter 4, on Jonson's Catiline, moves into a more literal discussion of Ciceronian emulation, appropriate to a play populated by historically imitative characters. Here, Dickson returns to Girard's work to set up a contrast with Jonson, who aims at a more positive reading of emulation's self-improving aspects over destructive enviousness. Jonson depicts Cicero's flaws and strengths in an effort to embody his personal belief in a need for multiple sources, as well as articulating admiration falling just short of idolatry. This chapter pictures Jonson writing with a nuanced, revisionary approach to selffashioning that disregards the Aristotelian interest in intent to favour a more external judgment of observable emulation (103). Chapter 5, on The Roman Actor, makes the case for an improved critical opinion of Massinger as playwright. Dickson argues that this play's concern with the power of drama to effect social change shows a tactical use of emulation on Massinger's part. As part of a cultural rediscovery of Tacitus, who emulated Cicero himself, the playwright presents a balanced argument for the ability of drama to affect social change. Both Massinger and Dickson conclude that theatre 'is a tool ... that is at the mercy of those in power' (146), neither self-evidently good nor evil, but dangerous in that enacting emulative theory onstage leaves interpretation in the hands of the audience. The afterword seeks to reinforce a wider, cultural emphasis on emulative practices.

That emulation has 'a thousand sons' may have been a sticking point for the style and structure of the overall work. Dickson's admission that 'dozens of other works could have provided equally revealing analysis' (171) of the patterns and practices of emulation reveals something about the cluttered style of the book. Emulation on the Shakespearean Stage is crowded with references to classical philosophers and rhetoricians and so, appropriately, the footnote citations are numerous. Unfortunately, on many pages they threaten to overwhelm the text and so distract the eye. The footnotes either are full of import necessary to understanding the topic, in which case they should be incorporated into the main argument, or are supplementary or digressive, in which case they would be better placed as endnotes. Certainly, the massive commentary proves Dickson's wealth of knowledge, but for ease of 
reading the book as a whole would benefit from paring down the notes. For the reader interested in rhetorical scholarship, Dickson's book may be invaluable for the extensive bibliography represented in his footnotes: he provides multiple citations for further reading on almost every major point.

My major concern with this book is not to do with its content or its presentation per se, but with the fact that a monograph with this content presented in this way has been issued in a series called 'Studies in Performance and Early Modern Drama', a series attempting 'to understand the complications of performance produced on stage and interpreted by the audience' (General Editor's Preface). The online version of the series outline is even more explicitly geared toward the physical and practical concerns of early modern drama, presented through 'original research on theatre histories and performance histories' and 'critiques of early modern drama that take into account the production values of the plays and rely on period records of performance' (Ashgate series main page). ${ }^{1}$ Dickson does sometimes brush against the kind of analysis that is directly useful for performers, but it routinely stops short of engaging with the practical matters of performing rhetorical language. In chapter 2, for example, his description of Ophelia's collapse into madness as a rhetorical counterpoint to Hamlet's careful self-construction (63-4) touches on something potentially performable by modern actors but, frustratingly, it cuts away after only a paragraph's attention. Again, in chapter 5, when he connects Massinger's work to Jonson's, and then to the contemporary political environment and feelings about Charles I, Dickson flirts with performative ideas without making explicit the relevant contextual information about enactment and reception. Unfortunately, neither instance fully delves into the 'how', which would be helpful to a practitioner. His aim is not to create a rhetorical workbook for modern actors, which is perfectly acceptable, but any suggestions for how other characters onstage fit into or react to rhetorical patterns, grounded in Dickson's thorough comprehension of the intricacies of tone and function, would have placed this book more comfortably in this otherwise performance-oriented imprint. Readers looking for a rhetorical primer should turn elsewhere; practitioners looking for analysis of emulatio have a thorough resource, though one that will require a fair bit of translation on their parts; scholars well-versed in emulative theory will find an engrossing and complex treatment of rhetorical patterns in four case study plays. 


\section{Notes}

1 'Studies in Performance and Early Modern Drama', Ashgate. https://www.ashgate. com/default.aspx?page $=5097 \&$ series_id $=264 \&$ calcTitle $=1$

Sarah E. Johnson. Staging Women and the Soul-Body Dynamic in Early Modern England. Farnham: Ashgate, 2014. Pp 185.

KRISTEN POOLE

Early Theatre 18.1 (2015), 159-62

University of Delaware

DOI: http://dx.doi.org/10.12745/et.18.1.2578

Sarah Johnson's Staging Women and the Soul-Body Dynamic, as its title suggests, is predicated on a binary that was fundamental to early modern epistemologies: that of the soul and body. As Johnson discusses, this binary was an inheritance of classical sources. As she explains, 'the Platonic view in the Renaissance saw the soul as the rightful moral governor of a body that was an encumbrance to it, a prison, clog, or dunghill that the soul longed to escape' (9). Aristotle's position, that 'the body [w] as necessary and good for the soul' (9), would seem to provide a counter position of soul-body integration, but his division of the soul (into the irrational and rational soul, the latter of which is further divided into active and passive intellect) ends up re-inscribing a hierarchical dualism. Aristotle's notion that the soul generates from male semen (an idea that would wend its way through Augustine), moreover, contributed not only to a soul-body dualism, but to a gendering of that binary: in Western theology and philosophy, when the soul and body were paired together, the soul was gendered masculine and the body was gendered feminine.

This binary (of masculine soul and feminine body) lies at the heart of early modern ideas of gender, argues Johnson: 'Men, who were supposedly not as prone to bodily influence, were considered more able to exercise reason, a faculty of the soul, and theological ideas that God ordained the soul to govern the body, and man to govern woman, were naturalized through cross-reference or analogy' (33). While it would be easy to consider this hierarchy of (masculine) soul and (feminine) body as just another form of patriarchal dominance, Johnson demonstrates ways in which the binary was 